\title{
The Effectiveness of Ivermectin on the Risk of Mortality in COVID-19 Patients: A Meta Analysis
}

\author{
Ayu Trisni Pamilih"), Didik Gunawan Tamtomo'), Bhisma Murti') \\ ${ }^{1)}$ Masters Program in Public Health, Universitas Sebelas Maret \\ ${ }^{2)}$ Faculty of Medicine, Universitas Sebelas Maret
}

\section{ABSTRACT}

Background: The Coronavirus Disease 2019 (COVID-19) has become the highest priority of global pandemic. New and repurposed drugs are being tested on mild to moderate levels of COVID19 to help suppress transmission of the virus. Ivermectin is one of the repurposed drugs with known safety records with more than 2.5 billion doses dispensed in the past. This study aims to estimate the effectiveness of ivermectin in reducing the risk of mortality in COVID-19 patients based on the results of a number of previous similar studies.

Subjects and Method: This study is a systematic review and meta-analysis. This study used secondary data in the form of data from previous study results. A systematic and comprehensive database search was carried out through several databases including: PubMed, Science Direct, Google Scholar, and Springer Link. Analysis of this study was using RevMan 5.3 software. This study used the eligibility criteria with the PICO model, populations: covid-19 patients, intervention: ivermectin administration, comparison: patients without ivermectin, outcome: mortality in COVID-19 patients. The inclusion criteria used were full paper in English and Indonesian with a randomized controlled trial, including the number of deaths, and the primary study was conducted in a hospital. The keywords used to search the database were "ivermectin" AND "COVID-19" OR "SARS-COV-2" AND "mortality" OR "death" AND "randomized controlled trial". Meta Analysis using RevMan 5.3 with Fixed Effect Model (FEM).

Results: Based on the results of the analysis, there is homogeneity of data between studies $\left(\mathrm{I}^{2}=\right.$ $0 \% ; p=0.940$ ) so that the Fixed Effect Model (FEM) is used. The use of ivermectin in COVID-19 patients reduced the median risk of death by 0.46 times compared to patients who were not given ivermectin $(\mathrm{aOR}=0.46$; CI 95\%=0.29 to $0.72 ; \mathrm{p}<0.001)$.

Conclusion: Ivermectin is effective in reducing the average risk of mortality in COVID-19 patients.

Keywords: COVID-19, Ivermectin, Mortality

\section{Correspondence:}

Ayu Trisni Pamilih. Masters Program in Public Health, Universitas Sebelas Maret. Jl. Ir. Sutami 36A, Surakarta 57126, Central Java, Indonesia. Email: trisniayu97@gmail.com. Mobile: 081393622900.

Cite this as:

Pamilih AT, Tamtomo DG, Murti B (2021). The Effectiveness of Ivermectin on the Risk of Mortality in COVID-19 Patients: A Meta Analysis. J Epidemiol Public Health. 06(04): 402-414. https://doi.org/10.26911/jepublichealth.2021.06.04.02. Attribution-NonCommercial-ShareAlike 4.o International License.

BACKGROUND

Coronavirus disease 2019 (COVID-19), caused by the new acute respiratory syndrome coronavirus 2 (SARS-CoV-2), has become the highest priority global pandemic. The number of cases in the world has more than 200 million people and about 5 million people have died (Johns Hopkins 
University of Medicine, 2021). Indonesian data shows more than 4 million cases of COVID-19, around 100 thousand died (COVID-19 Task Force, 2021). Several types of corona-virus are known to cause respiratory tract infections in humans ranging from coughs and colds to more serious ones such as Middle East Respiratory Syndrome (MERS) and Severe Acute Respiratory Syndrome (SARS). A new type of coronavirus that was found is the cause of COVID-19 disease. COVID-19 is an infectious disease caused by a newly discovered type of coronavirus. This new virus and the disease it causes were unknown before the outbreak began in Wuhan, China, in December 2019(WHO, 2021).

Available data suggest that a third of SARS-CoV-2 infections are asymptomatic, but uncertainty remains. Approximately $80 \%$ of symptomatic cases present with mild symptoms, including cough, fever, myalgia, headache, dyspnea, sore throat, diarrhea, nausea and vomiting, and loss of smell and taste. Outpatient management is appropriate for most people with mild COVID-19. Moderate, severe, and critical cases (approximately 20\%), with the need for oxygen supplementation, ventilatory support, or intensive medical care therapy, place a considerable burden on the health care system (Huang et al., 2020; WHO, 2021).

New and repurposed drugs are being tested on mild to moderate levels of COVID-19 to help in suppressing the transmission of the virus and prevent disease progression. Ivermectin is one of the repurposed drugs with known safety records with more than 2.5 billion doses dispensed in the past. Originally introduced as an anthelminthic agent, it has recently been found to have antiviral, anti-inflammatory and anti-cancer actions as well. Laboratory testing shows that ivermectin can slow the reproduction of the COVID-19 virus (SARS-CoV-2) but this needs further research in humans (Caly et al., 2020).

Ivermectin may be safe, affordable, and available. Therefore, the use of ivermectin guarantees rapid implementtation of controlled clinical trials to assess efficacy on SARS-CoV-2. There are observational studies showing the beneficial effects of ivermectin in the treatment of COVID-19 (Alam et al., 2020).

Meta-analysis studies are epidemiological studies that statistically combine the results of a number of primary studies that can be combined to obtain a quantitative overview (Huque, 1988; Greenhalgh, 1997; Last, 2001; Delgano-Rodriguez, 2001 in Murti 2018). This study aims to estimate the effectiveness of ivermectin in reducing the risk of mortality in COVID-19 patients based on the results of a number of previous similar studies.

\section{SUBJECTS AND METHOD}

\section{Study Design}

This is a systematic review and metaanalysis study. This study used secondary data in the form of data from the results of previous studies. This study was conducted by searching and selecting data from the results of clinical trials conducted around the world with different ethnicities, races, and locations. Filtering articles using PRISMA flow diagrams. Systematic and comprehensive database searches were carried out through several of them: PubMed, Science Direct, Google Scholar, and Springer Link between 2020 and 2021. The keywords used to search the database were "ivermectin" AND "COVID-19" OR "SARSCOV-2" AND "mortality" OR "death" AND "randomized controlled trial".

\section{Inclusion Criteria}

The inclusion criteria in this study were full paper articles, appropriate titles, articles 
selected depending on ivermectin which affects the incidence of death in patients with COVID-19, randomized controlled trials studies, articles published in English and Indonesian.

\section{Exclusion Criteria}

The exclusion criteria in this study were articles that did not include the number of deaths, articles before 2020, the control group was not patients without ivermectin administration.

\section{Definition of Operational Variables}

Search articles using the eligibility criteria with the PICO model. Populations: COVID19 patients. Intervention: administration of ivermectin. Comparison: patients without ivermectin. Outcome: Death in COVID-19 patients.

\section{Ivermectin}

It is an antiparasitic agent belonging to the avermectins group, originally a fermentative metabolite produced by the bacterium Streptomyces avermitilis. Instruments: published articles. Measurement scale: categorical

\section{Death of COVID-19 Patients}

It is when the function of the heart system, circulation, and respiratory system is proven to have stopped permanently. The focus in this study is the number of deaths in COVID-19 patients. Instruments: results on published articles. Measurement scale: categorical. Measuring results: dead and not dead

\section{Study Instruments}

This study used PRISMA Flow Diagrams and study quality used a critical appraisal checklist for randomized controlled studies published by CEBM University of Oxford 2014 (CEBM, 2014).

\section{Data Analysis}

Data analysis in this study used the Review Manager application (RevMan 5.3). Forest plots and funnel plots were used to determine the effect size and heterogeneity of the data. The fixed effect model is a statistical model used to combine the effects of various studies in a meta-analysis that assumes homogeneity of effects across the combined studies. Meanwhile, the random effect model is a statistical model used to combine the effects of various studies in a meta-analysis where heterogeneity between studies is included in the combined estimate by including the variance between studies (Delgano-Rodriguez, 2001 in Murti, 2018).

\section{RESULTS}

The article search process is carried out by identifying articles from 2020 to 2021 using a database search engine consisting of: PubMed, Science Direct, Google Scholar, and Springer Link. The keywords used to search the database were "ivermectin" AND "COVID-19" OR "SARS-COV-2" AND "mortality" OR "death" AND "randomized controlled trial".

The article review process can be seen in Figure 2. The results of the article search found 1,261 articles that were identified, then the multiple data was removed by 298 articles, then 963 articles were filtered. Based on the filtered articles, there were 936 articles issued and 32 articles were found that were considered eligible. Several full text articles after the assessment did not fulfill the requirements because the comparison in studies contained ivermectin, the outcome of the study was not appropriate, such as length of healing time, length of time hospitalized, reduced virus in the patient's body, severity in patients and others.

The articles that fulfilled the qualitative requirements were reviewed again and the researcher found 2 articles that did not fulfill the requirements in the presence of a combination of ivermectin with other drugs in the intervention group and did not 
include the number of mortality. The final result of the article review showed that there were 10 articles that fulfilled the quantitative requirements for meta-analysis.

Articles obtained from the results of the review are research originating from several countries, which can be seen in Figure 1. The results of the assessment of study quality are guided by the critical appraisal tools Randomized Controlled Trials (RCT) published by the Critical Apprisal Skills Program. This study has a strong quality, it can be seen in Table 1.

The results of the meta-analysis are presented in the form of a forest plot. The Forest Plot is a diagram showing information from each of the studies and an estimate of the overall results. In addition to the forest plot, this meta-analysis also presents a funnel plot, which is a diagram that illustrates the possibility of publication bias by showing the relationship between the study effect size and the sample size of the various studies being studied. The existence of publication bias in the funnel plot can be assessed by looking at the asymmetry of the funnel shape, the number of points on the right and left sides compared to the standard error (Murti, 2018). There were 10 articles identified from the results of the review that fulfilled the requirements as a source of metaanalysis of the effectiveness of using ivermectin on mortality in COVID-19 patients. An overview of each study can be seen in Table 2.

Based on the results of the analysis in Figure 3, it can be seen that there were 10 articles which reported that the administration of ivermectin could reduce the average mortality in COVID-19 patients. Based on the results of the analysis, there was no heterogeneity $\left(I^{2}=0 \% ; p=0.940\right)$ so the Fixed Effect Model (FEM) was used. The use of ivermectin in COVID-19 patients reduced the median risk of death by 0.46 times compared with patients not given ivermectin $(\mathrm{aOR}=0.46 ; 95 \% \mathrm{CI}=0.29$ to $0.72 ; \mathrm{p}<0.001)$. Based on Figure 4 funnel plot of the effectiveness of ivermectin use on mortality in COVID-19 patients, the plots on the right and left sides are symmetrical to each other and form an inverted funnel. The left-right plot has a standard error of $<0.5$ and has a standard error of $>1.5$, this indicated that there was no publication bias in this study.

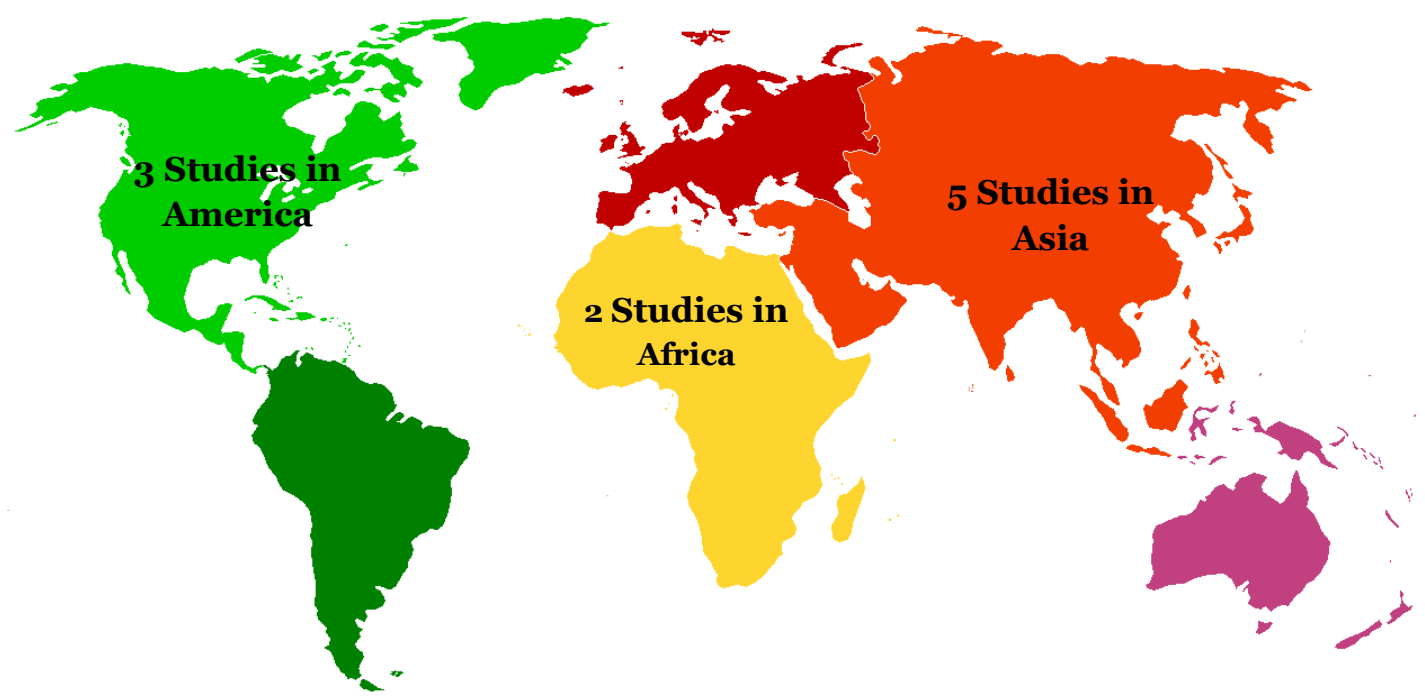

Figure 1. Map of Study Areas on the Effectiveness of
Ivermectin Use on Mortality in COVID-19 Patients 
Pamilih et al./ The Effectiveness of Ivermectin on the Risk of Mortality in COVID-19 Patients

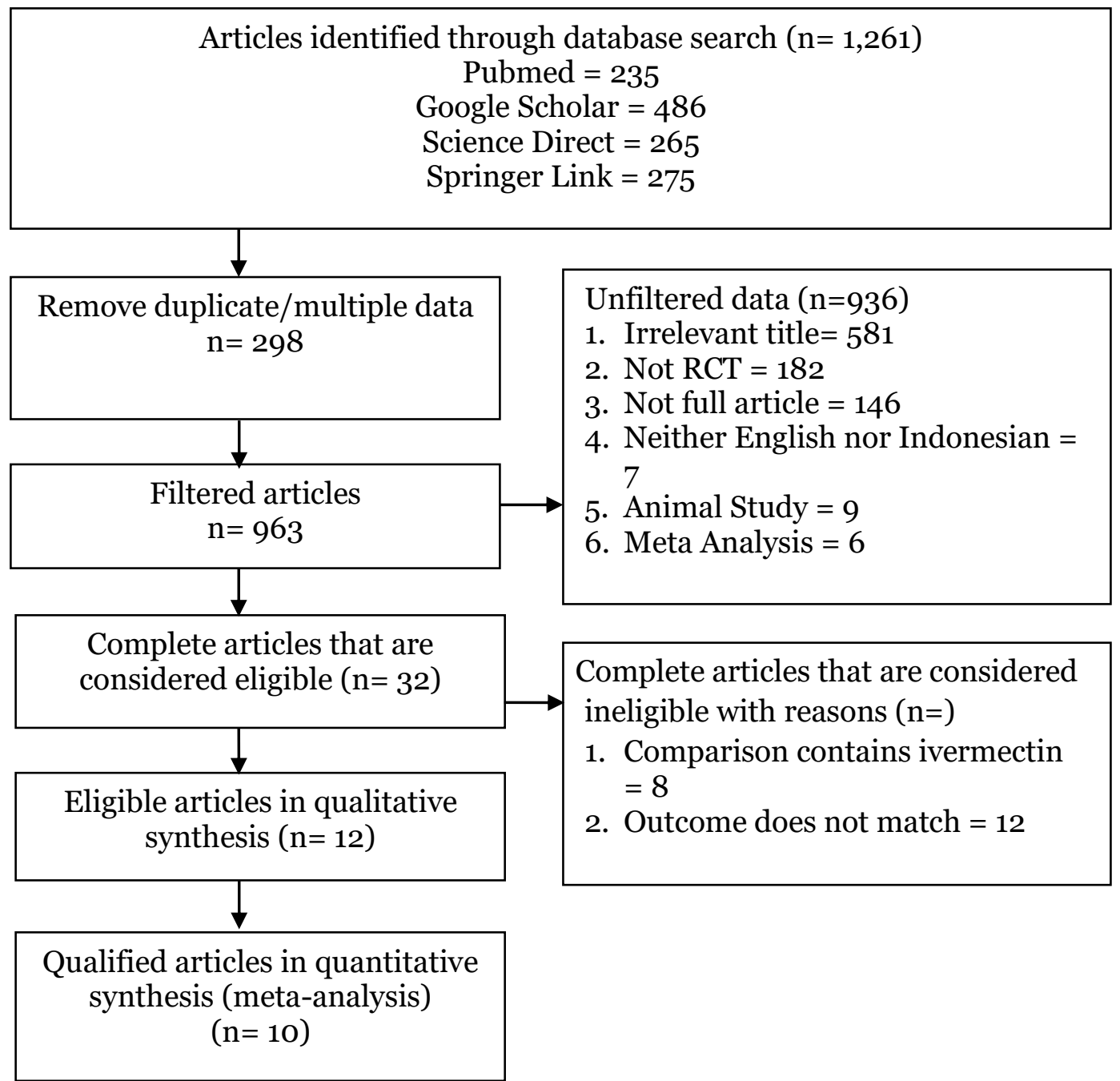

Figure 2. PRISMA flow diagrams The Effect of Residence on the Risk of Anxiety and Depression in the General Population During the COVID-19 Pandemic

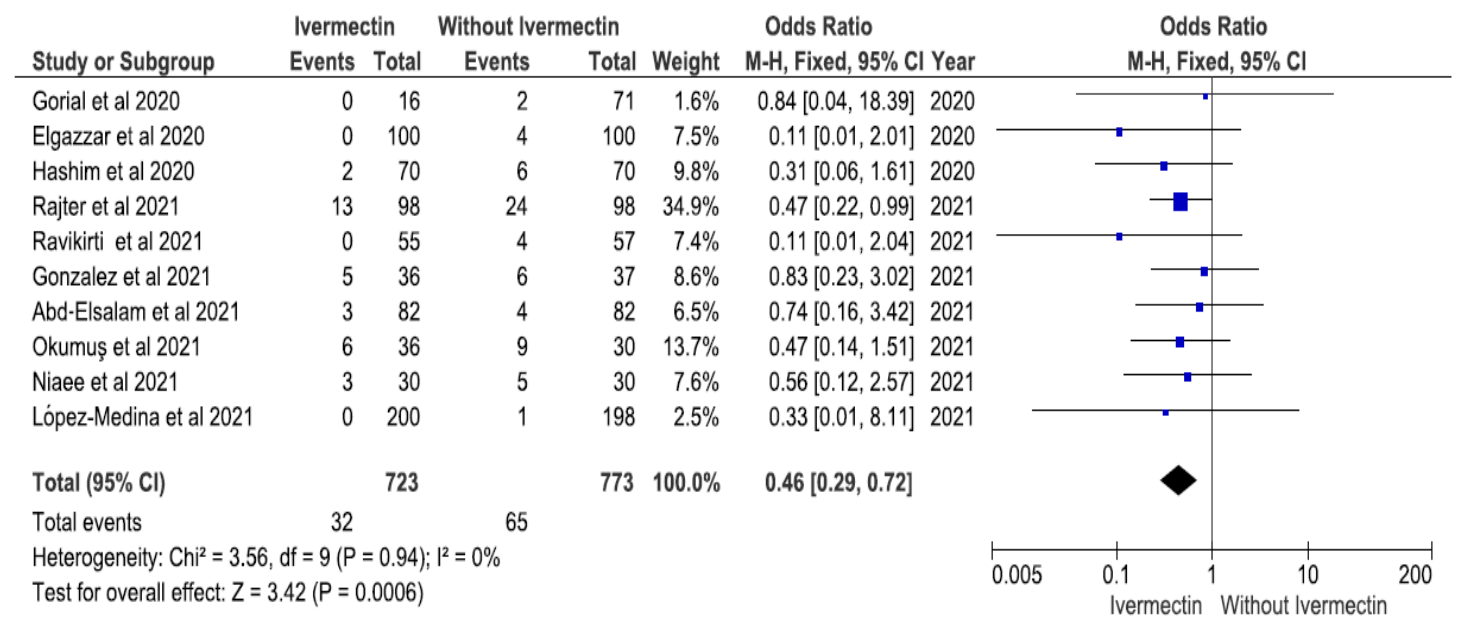

Figure 3. Forest Plot of the Effectiveness of Ivermectin Use on Mortality in COVID-19 Patients 
Table 1. Critical Apprisal Checklist Effectiveness of Ivermectin Use on Mortality in COVID-19 Patients

\begin{tabular}{|c|c|c|c|c|c|c|}
\hline \multirow[b]{2}{*}{ No } & \multirow[b]{2}{*}{ Checklist Questions } & \multicolumn{5}{|c|}{ Publication (Author and Year) } \\
\hline & & $\begin{array}{l}\text { Abd-Elsalam } \\
\text { et al, 2021 }\end{array}$ & $\begin{array}{l}\text { Elgazzar et } \\
\text { al, } 2020\end{array}$ & $\begin{array}{l}\text { Gonzalez et } \\
\text { al, } 2021\end{array}$ & $\begin{array}{l}\text { Gorial et } \\
\text { al, } 2020\end{array}$ & $\begin{array}{l}\text { Hashim et } \\
\text { al, } 2020\end{array}$ \\
\hline 1 & $\begin{array}{l}\text { Does the research address clearly focused } \\
\text { statements/problems? }\end{array}$ & 1 & 1 & 1 & 1 & 1 \\
\hline 2 & $\begin{array}{l}\text { Is the Randomized Controlled Trials (RCT) method } \\
\text { appropriate to answer the study question? }\end{array}$ & 1 & 1 & 1 & 1 & 1 \\
\hline 3 & $\begin{array}{l}\text { Are there enough subjects in the study to establish } \\
\text { that the findings did not occur by chance? }\end{array}$ & 1 & 1 & 1 & 1 & 1 \\
\hline 4 & $\begin{array}{l}\text { Are subjects randomly allocated to the experimental } \\
\text { group and the control group? If not can this be } \\
\text { biased? }\end{array}$ & 1 & 1 & 1 & 1 & 1 \\
\hline 5 & Are inclusion/exclusion criteria used? & 1 & 1 & 1 & 1 & 1 \\
\hline 6 & $\begin{array}{l}\text { Are the two groups comparable at the start of the } \\
\text { study? }\end{array}$ & 1 & 1 & 1 & 1 & 1 \\
\hline 7 & Are objective and unbiased outcome criteria used? & 1 & 1 & 1 & 1 & 1 \\
\hline 8 & $\begin{array}{l}\text { Are objective and validated measurement methods } \\
\text { used in measuring the results? If not, are results } \\
\text { judged by someone who is not aware of the group } \\
\text { assignment (i.e. is the assessment blinded?) }\end{array}$ & 1 & 1 & 1 & 1 & 1 \\
\hline 9 & Is effect size practically relevant? & 1 & 1 & 1 & 1 & 1 \\
\hline 10 & $\begin{array}{l}\text { How precise is the estimate of the effect? Is there a } \\
\text { confidence interval? }\end{array}$ & 1 & 1 & 1 & 1 & 1 \\
\hline 11 & $\begin{array}{l}\text { Could there be confounding factors that have not } \\
\text { been taken into account? }\end{array}$ & 1 & 1 & 1 & 1 & 1 \\
\hline 12 & Can the results be applied to your research? & 1 & 1 & 1 & 1 & 1 \\
\hline & Total & 12 & 12 & 12 & 12 & 12 \\
\hline
\end{tabular}

Description:

1: Yes

o: No 


\section{Continuation}

\begin{tabular}{|c|c|c|c|c|c|c|}
\hline \multirow[b]{2}{*}{ No } & \multirow[b]{2}{*}{ Checklist Questions } & \multicolumn{5}{|c|}{$\begin{array}{l}\text { Publication (Author and Year) } \\
\end{array}$} \\
\hline & & $\begin{array}{l}\text { López-Medina } \\
\text { et al, } 2021\end{array}$ & $\begin{array}{l}\text { Rajter et al, } 0 \\
2021\end{array}$ & $\begin{array}{l}\text { Okumuş et } \\
\text { al, } 2021\end{array}$ & $\begin{array}{l}\text { Ravikirti et } \\
\text { al, 2021 }\end{array}$ & $\begin{array}{l}\text { Niaee et al, } \\
\text { 2021 }\end{array}$ \\
\hline 1 & $\begin{array}{l}\text { Does the research address clearly focused } \\
\text { statements/problems? }\end{array}$ & 1 & 1 & 1 & 1 & 1 \\
\hline 2 & $\begin{array}{l}\text { Is the Randomized Controlled Trials (RCT) method } \\
\text { appropriate to answer the research question? }\end{array}$ & 1 & 1 & 1 & 1 & 1 \\
\hline 3 & $\begin{array}{l}\text { Are there enough subjects in the study to establish } \\
\text { that the findings did not occur by chance? }\end{array}$ & 1 & 1 & 1 & 1 & 1 \\
\hline 4 & $\begin{array}{l}\text { Are subjects randomly allocated to the } \\
\text { experimental group and the control group? If not } \\
\text { can this be biased? }\end{array}$ & 1 & 1 & 1 & 1 & 1 \\
\hline 5 & Are inclusion/exclusion criteria used? & 1 & 1 & 1 & 1 & 1 \\
\hline 6 & $\begin{array}{l}\text { Are the two groups comparable at the start of the } \\
\text { study? }\end{array}$ & 1 & 1 & 1 & 1 & 1 \\
\hline 7 & Are objective and unbiased outcome criteria used? & 1 & 1 & 1 & 1 & 1 \\
\hline 8 & $\begin{array}{l}\text { Are objective and validated measurement methods } \\
\text { used in measuring the results? If not, are results } \\
\text { judged by someone who is not aware of the group } \\
\text { assignment (i.e. is the assessment blinded?) }\end{array}$ & 1 & 1 & 1 & 1 & 1 \\
\hline 9 & Is effect size practically relevant? & 1 & 1 & 1 & 1 & 1 \\
\hline 10 & $\begin{array}{l}\text { How precise is the estimate of the effect? Is there a } \\
\text { confidence interval? }\end{array}$ & 1 & 1 & 1 & 1 & 1 \\
\hline 11 & $\begin{array}{l}\text { Could there be confounding factors that have not } \\
\text { been taken into account? }\end{array}$ & 1 & 1 & 1 & 1 & 1 \\
\hline 12 & Can the results be applied to your research? & 1 & 1 & 1 & 1 & 1 \\
\hline & Total & 12 & 12 & 12 & 12 & 12 \\
\hline
\end{tabular}

\section{Description:}

1: Yes

o: No 
Table 2. Summary Source of the Effectiveness of Ivermectin Use on Mortality in COVID-19 Patients

\begin{tabular}{|c|c|c|c|c|c|c|c|c|c|}
\hline \multirow[b]{2}{*}{ No } & \multirow[b]{2}{*}{ Author } & \multirow[b]{2}{*}{ Country } & \multirow[b]{2}{*}{$\begin{array}{l}\text { Study } \\
\text { Design }\end{array}$} & \multicolumn{2}{|c|}{ Total Sample } & \multirow[b]{2}{*}{$\begin{array}{c}\text { Population } \\
\text { (P) }\end{array}$} & \multirow[b]{2}{*}{$\begin{array}{c}\text { Intervention } \\
\text { (I) }\end{array}$} & \multirow[b]{2}{*}{$\begin{array}{c}\text { Comparison } \\
\text { (C) }\end{array}$} & \multirow[b]{2}{*}{$\begin{array}{c}\text { Outcome } \\
\text { (O) }\end{array}$} \\
\hline & & & & $\begin{array}{l}\text { COVID- } \\
19 \\
\text { Patients }\end{array}$ & $\begin{array}{c}\text { Administra } \\
\text { tion of } \\
\text { Ivermectin }\end{array}$ & & & & \\
\hline 1 & $\begin{array}{l}\text { Abd-Elsala } \\
\text { m et al, } \\
2021\end{array}$ & Egypt & RCT & 164 & 82 & $\begin{array}{l}\text { COVID-19 } \\
\text { confirmed } \\
\text { patient }\end{array}$ & Ivermectin & $\begin{array}{l}\text { Without } \\
\text { Ivermectin }\end{array}$ & Mortality \\
\hline 2 & $\begin{array}{l}\text { Elgazzar et } \\
\text { al, } 2020\end{array}$ & Egypt & RCT & 200 & 100 & $\begin{array}{l}\text { COVID-19 } \\
\text { confirmed } \\
\text { patient }\end{array}$ & Ivermectin & $\begin{array}{l}\text { Without } \\
\text { Ivermectin }\end{array}$ & Mortality \\
\hline 3 & $\begin{array}{l}\text { Gonzalez et } \\
\text { al, } 2021\end{array}$ & Mexico & RCT & 73 & 36 & $\begin{array}{l}\text { COVID-19 } \\
\text { confirmed } \\
\text { patient }\end{array}$ & Ivermectin & $\begin{array}{l}\text { Without } \\
\text { Ivermectin }\end{array}$ & Mortality \\
\hline 4 & $\begin{array}{l}\text { Gorial et al, } \\
2020\end{array}$ & Iraq & RCT & 87 & 16 & $\begin{array}{l}\text { COVID-19 } \\
\text { confirmed } \\
\text { patient }\end{array}$ & Ivermectin & $\begin{array}{l}\text { Without } \\
\text { Ivermectin }\end{array}$ & Mortality \\
\hline 5 & $\begin{array}{l}\text { Hashim et } \\
\text { al, } 2020\end{array}$ & Iraq & RCT & 140 & 70 & $\begin{array}{l}\text { COVID-19 } \\
\text { confirmed } \\
\text { patient }\end{array}$ & Ivermectin & $\begin{array}{l}\text { Without } \\
\text { Ivermectin }\end{array}$ & Mortality \\
\hline 6 & $\begin{array}{l}\text { López- } \\
\text { Medina et } \\
\text { al, } 2021\end{array}$ & USA & RCT & 398 & 200 & $\begin{array}{l}\text { COVID-19 } \\
\text { confirmed } \\
\text { patient }\end{array}$ & Ivermectin & $\begin{array}{l}\text { Without } \\
\text { Ivermectin }\end{array}$ & Mortality \\
\hline 7 & $\begin{array}{l}\text { Niaee et al, } \\
2021\end{array}$ & Iran & RCT & 60 & 30 & $\begin{array}{l}\text { COVID-19 } \\
\text { confirmed } \\
\text { patient }\end{array}$ & Ivermectin & $\begin{array}{l}\text { Without } \\
\text { Ivermectin }\end{array}$ & Mortality \\
\hline 8 & $\begin{array}{l}\text { Okumuş et } \\
\text { al, } 2021\end{array}$ & Turkey & $\mathrm{RCT}$ & 66 & 36 & $\begin{array}{l}\text { COVID-19 } \\
\text { confirmed } \\
\text { patient }\end{array}$ & Ivermectin & $\begin{array}{l}\text { Without } \\
\text { Ivermectin }\end{array}$ & Mortality \\
\hline 9 & $\begin{array}{l}\text { Rajter et al, } \\
2021\end{array}$ & USA & $\mathrm{RCT}$ & 296 & 98 & $\begin{array}{l}\text { COVID-19 } \\
\text { confirmed } \\
\text { patient }\end{array}$ & Ivermectin & $\begin{array}{l}\text { Without } \\
\text { Ivermectin }\end{array}$ & Mortality \\
\hline 10 & $\begin{array}{l}\text { Ravikirti et } \\
\text { al, } 2021\end{array}$ & India & $\mathrm{RCT}$ & 112 & 55 & $\begin{array}{l}\text { COVID-19 } \\
\text { confirmed } \\
\text { patient }\end{array}$ & Ivermectin & $\begin{array}{l}\text { Without } \\
\text { Ivermectin }\end{array}$ & Mortality \\
\hline
\end{tabular}




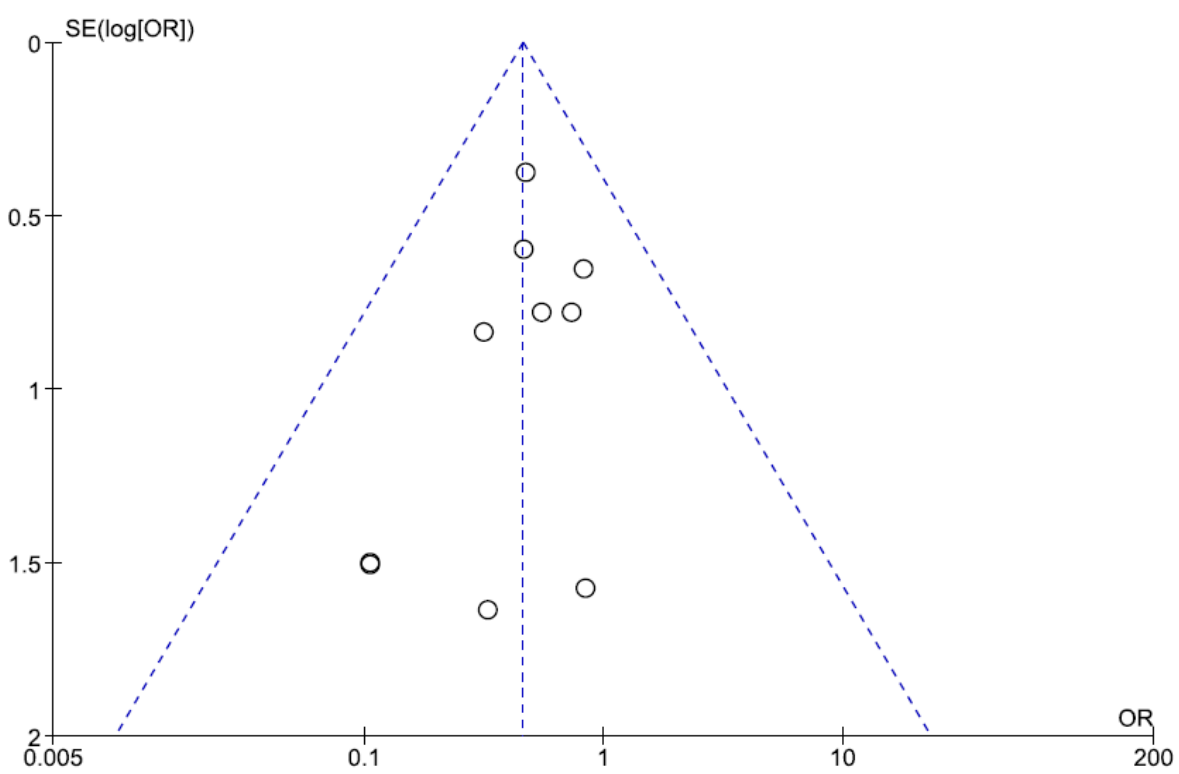

Figure 4. Funnel Plot of the Effectiveness of Ivermectin Use on Mortality in COVID-19 Patients

\section{DISCUSSION}

Coronavirus disease (COVID-19) is an infectious disease caused by the SARS-CoV2 virus (WHO, 2021). Coronavirus disease 2019 (COVID-19), caused by the new acute respiratory syndrome coronavirus 2 (SARSCoV-2), has become the highest priority global pandemic. The number of cases in the world has more than 200 million people and about 5 million people have died (Johns Hopkins University of Medicine, 2021). Most people infected with the virus will develop mild to moderate respiratory illness and recover without requiring special treatment. However, some will become seriously ill and require medical attention. Patients with SARS-CoV-2 infection can show symptoms ranging from mild to severe with most of the population being asymptomatic carriers. The most commonly reported symptoms included fever (83\%), cough (82\%) and shortness of breath (31\%) (Elgazzar, 2020). Transmission of SARSCoV-2 occurs with high efficacy and infectivity, mainly through the respiratory route. Droplet transmission is the main known route, although aerosols may represent another important route (Han et al., 2020). Confirmed cases of COVID-19 are performed by laboratory examinations ReverseTranscriptase Polymerase-Chain-Reaction (RT-PCR) and Computed Tomography (CT) Scan of the chest (Hashim et al., 2020)

Ivermectin is an antiparasitic agent belonging to the avermectins group, originally a fermentable metabolite produced by the bacterium Streptomyces avermitilis. Ivermectin was introduced for medical use in 1982 and is elective against a wide variety of nematodes and helminths, and ectoparasites. Ivermectin is an FDA-approved broad-spectrum anti-parasitic agent that in recent years has been shown to have antiviral activity against a wide variety of viruses in vitro.

\section{The Effectiveness of Ivermectin Use} on Mortality in COVID-19 Patients

Based on the results of an analysis of 10 articles regarding the effectiveness of the use of ivermectin on mortality in COVID-19 patients, it was shown that administering ivermectin was effective in reducing the 
average risk of death in COVID-19 patients. Based on the results of the analysis, there was no heterogeneity $\left(\mathrm{I}^{2}=0 \% ; \mathrm{p}=0.940\right)$ therefore, the Fixed Effect Model (FEM) is used. The use of ivermectin in COVID-19 patients reduced the median risk of death by 0.46 times compared to patients who were not given ivermectin ( $\mathrm{aOR}=0.46 ; 95 \%$ $\mathrm{CI}=0.29$ to $0.72 ; \mathrm{p}<0.001)$.

An in vitro study conducted by Caly et al. (2020) showed that at 48 hours, this effect of ivermectin increased with the reduction of COVID-19 virus to a $\sim 5000$ times reduction in RNA virus in ivermectintreated compared to control samples, indicating that ivermectin treatment resulted in the effective disappearance of all viral material at 48 hours. Consistent with this idea, no further reduction in RNA virus was observed at 72 hours. Overall, these results suggest that ivermectin has antiviral action against clinical isolates of SARS-CoV-2 in vitro, with a single dose being able to control viral replication within 24-48 hours in the system. Ultimately, the development of effective antivirals for SARS-CoV-2, if it is given to patients in early infection, it could help to limit viral loads, prevent progression of severe disease and limit person-to-person transmission.

This study is supported by Elgazzar et al. (2020) which stated that addition of Ivermectin to standard care is a highly effecttive drug for the treatment of COVID19 patients with reductions in mortality, recovery time, and days of hospitalization compared to standard treatment only. Ivermectin has significantly reduced the incidence of infection in health care and household contacts by $2 \%$ compared with $10 \%$ in the non-ivermectin group when it is used as prophylactically.

Early use of Ivermectin is very useful for controlling COVID 19 infection. This is similar to a study reported by Gorial et al.,
(2020) which stated that additional use of Ivermectin (IVM) in standard care has a higher cure rate, shorter hospitalization days compared to controls. All patients in the IVM group recovered compared with controls [16 (100\%) compared with no ivermectin 69 (97.2\%)]. Two patients died in controls. In average, hospital stay was significantly lower in the IVM group compared to the control group (Mean= 7.62; $\mathrm{SD}=2.75$ compared with Mean=13.22 $\mathrm{SD}=5.90$ days; $\mathrm{p}<0.001)$. No side effects were observed in this study.

This study is in line with Okumu et al. (2021) who found that patients with the addition of ivermectin to regular care (study group) had a higher rate of clinical improvement compared to patients who received only regular care (control group). At the end of the study, the mortality rate was found to be lower in the study group compared to the control group. However, the clinical improvement and mortality differences between the study and control groups were not statistically significant.

The study of Rajter et al (2021) supports this study with lower hospital mortality in the intervention group than in the placebo group. In 280 patients, 173 of them were treated with ivermectin and 107 were treated without ivermectin. Univariate analysis showed lower mortality in the ivermectin group (15.0\% compared with no ivermectin 25.2\%; OR=0.52; 95\% CI $=0.29$ to $0.96 ; \mathrm{p}=0.030$ ). Mortality was also lower among ivermectin-treated patients with severe pulmonary involvement (38.8\% versus $80.7 \%$ without ivermectin; $\mathrm{OR}=$ $0.15 ; 95 \% \mathrm{CI}=0.05$ to $0.47 ; \mathrm{p}=0.001$ ). Ivermectin treatment is associated with lower mortality during COVID-19 treatment, especially in patients with severe pulmonary involvement.

Ravikirti et al. (2021) showed that a total of 115 patients were enrolled for the 
study of which 112 were included in the final analysis. In addition, 55 of them were randomized to the intervention group while 57 were randomized to the placebo group. There was no significant difference in the baseline characteristics of the two arms. There was no significant difference in the primary results, which was the negative RTPCR status on day 6 between the two groups. Similarly, there were no significant differences between the two groups in most of the secondary outcome measures, namely symptom status at day 6 , discharge status at day 10, ICU admission, and need for invasive mechanical ventilation. However, while there were no in-hospital deaths in the intervention group, there were 4 deaths in the placebo group. As a result, all patients in the intervention group $(n=56)$ were successfully discharged compared to the control group.

The meta-analysis conducted by Andrew et al. (2021) of 23 RCTs in 3,349 patients showed that ivermectin had a significant effect on faster viral clearance and a significant effect on limiting the duration of hospitalization. In the main analysis, excluding studies with a high risk of bias, there was no significant effect of ivermectin on survival or hospitalization $(\mathrm{RR}=0.90$; 95\% CI $=0.57$ to $1.42 ; \mathrm{p}=0.66$ ) or hospitalization $(\mathrm{RR}=0.63$; $95 \% \mathrm{CI}=0.36$ to $1.11 ; \mathrm{p}=$ 0.110). Recently, preliminary results from a trial (Mills et al, 2021) showed in a randomized, placebo-controlled study of ivermectin in more than 1200 outpatients, there was no significant effect of ivermectin on hospitalization or survival.

A meta-analysis conducted by Kow et al. (2021) with 6 articles of randomized controlled trials, the results are in line with this study that ivermectin administration affects mortality reduction in COVID-19 patients $(\mathrm{aOR}=0.21 ; 95 \% \mathrm{CI}=0.11$ to 0.42$)$. Several RCTs and observational studies have reported faster virus clearance with ivermectin. However, other studies have not found this benefit. So, there is a need for further, larger studies to validate the results of this study

The limitation of the study is that there is a language bias, because the study only uses articles in English, thus ignoring studies in other languages. There is also database bias, because the databases used are PubMed, Science Direct, Google Scholar, and Springer Link, therefore, this study ignores other database sources.

\section{AUTHORS CONTRIBUTION}

Ayu Trisni Pamilih is the main researcher who choosed the topic, selected articles and study data. Didik Gunawan Tamtomo and Bhisma Murti analyzed the data and reviewed study documents.

\section{FUNDING AND SPONSORSHIP}

This study was self-funded.

\section{CONFLICT OF INTEREST}

There was no conflict of interest in this study.

\section{ACKNOWLEDGMENT}

We would like to thank to PubMed, Google Scholar, Science Direct, and Springer Link database.

\section{REFERENCES}

Abd-Elsalam SA, Noor RA, Khalaf M, Medhat MA, Karam H, Ramadan A, Eldeen MAS, et al. (2021). Clinical study evaluating the efficacy of ivermectin in COVID-19 treatment: A randomized controlled study. J Med Virol. 2019: 10-15. doi: 10.1002/jmv.27122.

Alam MT, Murshed R, Bhiuyan E, Saber S, Alam RF, Robin RC (2020). A case series of 100 covid-19 positive pati- 
Pamilih et al./ The Effectiveness of Ivermectin on the Risk of Mortality in COVID-19 Patients

ents treated with combination of ivermectin and doxycycline. J. Bangladesh Coll. Phys. Surg. 38: 10-15. doi: 10.3329/jbcps.v38io.47512.

Andrew H, Anna G, Jacob L, Jonathan F, Leah E, Kaitlyn M, Victoria P, et al. (2021). Meta-analysis of randomized trials of ivermectin to treat SARSCoV-2 infection. Open Forum Infect Dis. 8(11): ofab358. doi: 10.1093/ofid/ofab358.

Caly L, Druce JD, Catton MG, Jans DA, Wagsta KM (2020). The FDAapproved drug ivermectin inhibits the replication of SARS-CoV-2 in vitro. J.Antiviral Research. 178: 3-6. doi: 10.1016/j.antiviral.2020.104787.

Campbell WC (1985). Ivermectin: An Update. Parasitology Today. 1:1. doi: 10.1016/0169-4758(85)90100-0.

CASP (2018). Critical appraisal skills programme randomised controlled trial standard checklist. Retrieved from https://casp-uk.b-cdn.net/wp-content/uploads/2020/10/CASP_RCT_ Checklist_PDF_Fillable_Form.pdf.

Elgazzar A, Eltaweel A, Youssef SA, Hany B, Hafez M, Moussa H (2020). Efficacy and safety of ivermectin for treatment and prophylaxis of COVID19 pandemic. J. Res. 1-10. doi: 10.21203/rs.3.rs-100956/v3.

Gorial FI, Sabeeh M, Hend MS, Basim DD, Marwan MA, Adnan MA, Hassan MA, Mohammed G, Jawad IR (2020). Effectiveness of ivermectin as add-on therapy in COVID-19 management. MedRxiv. 2(1): 2-13 doi: 10.1101/2020.07.07.20145979.

Gonzalez JLB, Gámez MG, Enciso EAM, Maldonado RJE, Palacios DH, Campos SD, Robles IO, et al. (2021). Efficacy and safety of ivermectin and hydroxychloroquine in patients with severe COVID-19. A randomized controlled trial. medRix. doi: 10.1101/2021.02.18.21252037

Han Q, Lin Q, Ni Z, You L (2020). Uncertainties about the transmission routes of 2019 novel coronavirus. J. irv. 14(4): 470-471. doi: 10.1111/irv.12735 .

Hashim A, Hashim MF, Maulood AM. Rasheed, Dhurgham F, Fatak, Khulood K, Kabah AS, Abdulamir (2020). Controlled randomized clinical trial on using Ivermectin with Doxycycline for treating COVID-19 patients in Baghdad, Iraq. medRxiv. doi: 10.1101/2020.10.26.20219345

Johns Hopkins University of Medicine COVID-19 (2021). COVID-19 dashboard by the center for systems science and engineering (CSSE) at Johns Hopkins University. Available at: https://coronavirus.jhu.edu/map.html. Accessed 2-12-2021.

Kow C, Merchant HA, Mustafa ZU. Hasan SS (2021). The association between the use of ivermectin and mortality in patients with COVID-19: a meta-analysis. Pharmacol Rep. 73:1473-1479. doi: $10.1007 / \mathrm{s} 43440-021-00245-\mathrm{Z}$

López-Medina E, López P, Hurtado IC, Davalos DM, Ramirez O, Martinez E, Diazgranados JA. et al. (2021). Effect of ivermectin on time to resolution of symptoms among adults with mild COVID-19: A randomized clinical trial. JAMA. 325(14): 1426-1435. doi: 10.1001/jama.2021.3071

Mills E. Early Treatment of COVID-19 with Repurposed Therapies: The TOGETHER Adaptive Platform Trial (2021). Retrieved from: https://rethinkingclinicaltrials.org/news/augus t-6-2021-early-treatment-of-covid19-with-repurposed-therapies-thetogether-adaptive-platform-trial- 
Pamilih et al./ The Effectiveness of Ivermectin on the Risk of Mortality in COVID-19 Patients

edward-mills-phd-frcp/. Accessed in 20 Desember 2021.

Murti B (2018). Prinsip dan metode riset epidemiologi edisi ke empat (principles and methods of epidemiological research, fourth edition). Surakarta: Universitas Sebelas Maret. Shakhsi Niaee M, Namdar P, Allami A, Zolghadr L, Javadi A, Karampour A, Vernasari M, et al. (2021) Ivermectin as an adjunct treatment for hospitalized adult COVID-19 patients: A randomized multi-center clinical trial. Asian Pac J Trop Med. 14(6): 266-273. doi: 10.4103/1995-7645.318304.

Okumu N, Çetinkaya A, Güner R, Ya İ, Orhan S (2021). Evaluation of the effectiveness and safety of adding ivermectin to treatment in severe COVID-19 patients. 1-11. BMC infect. dis. doi: 10.1186/s12879-021-061049.

Rajter JC, Sherman MS, and Fatteh N (2021). Use of ivermectin is associated with lower mortality in hos- pitalized patients with coronavirus disease 2019 The Ivermectin in COVID Nineteen Study. CHEST. 159(1): 85-92. doi: 10.1016/j.chest.2020.10.009.

Ravikirti, Roy R, Pattadar C, Raj R, Argawal N, Biswas B, Majhi PK, et al. (2021). Ivermectin as a potential treatment for mild to moderate COVID-19 - A double blind randomized placebo-controlled trial. medRxiv. doi: 10.1101/2021.01.05.21249310.

Satuan Tugas COVID-19 (2021). Peta sebaran COVID-19 di Indonesia, dasbor COVID-19 oleh pusat satuan tugas COVID-19 Indonesia (Map of the Spread of COVID-19 in Indonesia, COVID-19 Dashboard by the Center for the Indonesian COVID-19 Task Force). Available at: https://covid19.go.id/peta-sebaran-covid19.

WHO (2021). Coronavirus disease (COVID-19), Dashboard at WHO. Available at: https://covid-19.who.int/. Accessed in 2-12-21. 